\title{
Faculty Usage of Library Tools in a Learning Management System
}

\section{Chris Leeder and Steven Lonn}

\begin{abstract}
To better understand faculty attitudes and practices regarding usage of library-specific tools and roles in a university learning management system, log data for a period of three semesters was analyzed. Academic departments with highest rates of usage were identified, and faculty users and nonusers within those departments were surveyed regarding their perceptions of and experience with the library tools. Librarians who use the tools were also surveyed to compare their perceptions of faculty tool and role use. While faculty survey respondents showed high levels of positive perceptions of librarians, they also exhibited low awareness of the library tools and little understanding of their use. Recommendations for encouraging wider adoption and effective usage are discussed.
\end{abstract}

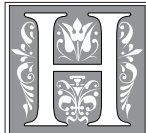

igher education institutions have rapidly and widely adopted the e-learning technologies variously called courseware, course management systems, virtual learning environments, or learning management systems (LMSs) in recent years. ${ }^{1}$ These online systems allow coordination, distribution, and retrieval of online course materials and facilitate online communication between instructors and students and among students themselves. ${ }^{2}$ Effective use of a LMS has been shown to improve the quality of teaching and learning and enrich the educational experience of students. ${ }^{3}$ The communication tools in LMSs can encourage active engagement in classes by students and promote constructivist rather than instructivist styles of learning. ${ }^{4}$ For academic libraries, incorporating library resources and services into a LMS offers the opportunity to improve library visibility, increase relevance with students, and strengthen relationships with faculty. ${ }^{5}$ Embedding library resources in LMSs can also help to increase the availability of those resources to students, encourage their use, and encourage interaction with librarians. ${ }^{6}$ In particular, a LMS can be used to scaffold Information Literacy (IL) instruction in course websites and incorporate information literacy activities throughout subject-specific courses. ${ }^{7}$ Integrating information literacy into LMS courses can be an effective way to improve library instruction and student learning. ${ }^{8}$

Despite the affordances of incorporating their services and resources, university libraries are rarely integrated into their institution's LMS due to a number of institutional factors. Librarians are infrequently involved in the administration and management

Chris Leeder is a doctoral candidate in the School of Information, University of Michigan, e-mail: cleeder@ umich.edu; Steven Lonn is Assistant Director of the USE Lab and Library Learning Analytics Specialist, University of Michigan, e-mail: slonn@umich.edu. (C2014 Chris Leeder and Steven Lonn, AttributionNonCommercial (http://creativecommons.org/licenses/by-nc/3.0/) CC BY-NC 
of courseware, must often negotiate with faculty to be given permission and access to a course website, and are often required to adapt pre-existing LMS roles such as instructor, graduate student instructor, curriculum support staff, or administrator. ${ }^{9}$ These barriers can create a perception of library marginalization in LMSs. ${ }^{10}$ In addition, some faculty are unaware of how the library might support their teaching and facilitate student learning. ${ }^{11}$ Since few LMSs include integrated library components, the full potential for delivering library resources and services into the classroom remains underused. ${ }^{12}$ In an environment of decreasing use of libraries by students, decreasing rates of IL instruction, and increasing use of online information resources by students, linking the LMS to libraries becomes even more critically important. ${ }^{13}$

To effectively promote faculty awareness and usage of the library tools in a LMS, better understanding of faculty attitudes and practices is needed. This information can be leveraged by libraries to effectively target their limited promotional resources toward faculty who are most likely to be receptive to adoption of these tools. Thus, the specific research questions guiding this study were:

1. Which departments have the highest usage of the library tools?

2. What significant differences exist between faculty users and nonusers of library tools?

3. How do faculty's perceptions of library resources and functions in the LMS differ from those of librarians?

This study investigated these questions through analysis of aggregated log data from the LMS and an online survey of faculty users, nonusers, and librarians and produced recommendations for encouraging wider adoption and effective usage of LMS library tools.

\section{Literature Review}

In recent years, integrating librarian services directly into the LMS course website has been termed "embedded librarianship," based on the media correspondents during the Iraq War who reported from within the events of the war and were termed embedded journalists. ${ }^{14}$ An embedded librarian takes an active role inside LMS course websites and works to integrate library services and practices into the teaching and learning process. Such practices have been effective for initiating and maintaining contact with faculty and promoting library visibility. ${ }^{15}$ Embedding library resources into LMS course websites ensures their availability to students, helps promotes their use, and can be a means to connect with students at their "point of need."16 Rather than waiting for students to visit them at the reference desk, embedded librarians can provide "just in time" assistance to students when they need it most and help students can see greater relevance of library resources. ${ }^{17}$ Since students are primarily concerned with their immediate class assignments, they are more likely to use library resources that are presented in an immediately accessible and convenient location. ${ }^{18}$ The LMS course website presents a natural opportunity to provide convenient access to library resources so that students do not have to go elsewhere to find what they need..$^{19}$ It has been suggested that this strategic, contextualized placement of library resources into a LMS better meets the needs of 21st-century learners by providing on-demand, pointof-need information embedded in the online environment, while also helping guide them away from instinctive reliance on Google searching and sources from the open web and toward the scholarly resources available through the library. ${ }^{20}$

Despite the literature promoting embedded librarians, there is a lack of well-defined functionality for library resources within most LMSs. ${ }^{21}$ The literature that documents librarian usage of LMS tools is often in the form of case studies that describe individual solutions that librarians have created at their institutions, often customized to individual 
courses. ${ }^{22}$ In a case study from Dominican University, a librarian describes being given "course builder" access to an LMS course website, allowing her to contribute to the class LMS site and interact with students online, providing individualized instruction targeted to the needs of the students in the class. ${ }^{23}$ In a case study from Harvard University, librarians describe developing a resource guide for Life Sciences library resources and tailoring versions for specific classes that were embedded in their LMS, as well as providing a venue for promoting additional library training resources. ${ }^{24}$ Response from faculty and students was positive. At The Ohio State University, librarians developed a tool to create customizable library resource pages within the LMS that allowed librarians to create multiple course-specific pages with little effort, with positive student responses received about the tool via a survey. ${ }^{25}$ At the University of North Carolina at Greensboro, librarians developed an LMS Library Portal that embeds course-specific library resource tools in class sites and reported a steady increase in use of the portal in comparison to page views of the primary library website. ${ }^{26}$ Librarians at North Carolina State University created a tool to create dynamically generated library resource pages for specific courses in the LMS, resulting in a ten-fold increase over the coverage that was previously possible with individually authored course guides. ${ }^{27}$ Buffalo State College librarians described the creation and implementation of a customized library module in their LMS and reported a dramatic rise in library database usage statistics. ${ }^{28}$ At Duke University, librarians used a specially designed LMS template to populate course pages with specific library resources. This initiative was evaluated through the use of surveys, interviews, and usability testing, with positive feedback providing the impetus for greater efforts toward automation of course-specific LibGuides. ${ }^{29}$ Overall, while these case studies provide individual examples of specific LMS library tool implementations, they do not include research into the usage patterns of the tools by actual users other than through webpage view counts.

Along with case studies, surveys are frequently represented in the literature on librarian usage in LMSs. A survey of librarians in the California State University system assessed their use of the LMS as a teaching and learning tool for information literacy skills and concluded that better integration of library resources into the LMS was needed.$^{30}$ Investigators at the University of Illinois at Urbana-Champaign surveyed librarians regarding the challenges and issues that they face in creating a presence for library instruction within the LMS and found that librarians needed more training and support from LMS adminsitrators. ${ }^{31}$ Seven United Kingdom universities explored the involvement of subject librarians with their LMS and, through a shared survey sent to librarians, identified several obstacles, including faculty resistance to assigning librarians a teaching role. ${ }^{32}$ At the Cornell University Library, faculty were asked to discuss their attitudes and practices with respect to the use of library resources within the university's LMS. The survey resulted in recommendations to the library administration on exploring how to better incorporate library resources into the LMS, emphasizing that students will expect to find library resources and services readily available in the LMS. ${ }^{33}$ Overall, these surveys of librarian usage of LMS library tools provides strong support for the importance of integrating library resources and services into the LMS.

While the literature includes many case studies of specific LMS library tool implementations and surveys of librarians' use of library resources in LMS, relatively little is known about faculty's actual use of specific library tools in LMS using analytic data. ${ }^{34}$ Since LMS library tools cannot be effective if they are not used by faculty, it is important to understand what factors may influence faculty use of such tools. Thus, this study responds to a gap in the literature by examining the faculty usage data of library tools in a LMS to determine characteristics that might distinguish users from nonusers, as well as surveying faculty regarding their attitudes and practices regarding those tools. 


\section{Description of the LMS Library Tools}

A customized LMS has been implemented at a large, public, four-year Midwestern research university with very high research activity and a majority undergraduate enrollment, according to the Carnegie Classification of Institutions of Higher Education (www.carnegiefoundation.org/ classifications/). This customized LMS is based on the Sakai community-source architecture (see www.sakaiproject.org), and its features are comparable to other widely used systems such as Blackboard (www.blackboard. com) and Moodle (www.moodle.org). When creating a specific course website in the LMS, creators first see a list of available tools, which the creator checks off to activate (see figure 1). Examples of standard tools that can be activated for course websites include: Announcements, Assignments, Chat room, Drop Box, Forum, Gradebook, etc. In this version of the LMS, two library-specific tools are included in the selection list: the "Library Help" tool, which allows students to chat via Instant Message with a librarian; and the "Library Materials" tool, which automatically links to any course materials on reserve in the university library. Both of these tools must be selected and "turned on" by the course instructor or an authorized user to be made active on the website. (Course websites may also be created by student assistants or other support staff rather than by the instructor of record.)

Once these tools have been turned on, they appear embedded within the LMS course website and are available to students anytime that they are logged in to the site (see figure 2). The Library Help chat reference tool is staffed by university librarians during regularly scheduled office hours; e-mail reference is available after hours.

A third, customized library-specific role has been created in this version of the LMS. Access to a course website can be authorized for a number of different participants (Affiliate, Assistant, Instructor, Observe, Owner, and Student), each with different permissions to read, revise, delete, and add content. A custom role for librarians has

\begin{tabular}{|c|c|}
\hline \multicolumn{2}{|c|}{$\begin{array}{c}\text { FIGURE } 1 \\
\text { Course Website Tool Options-My Workspace }\end{array}$} \\
\hline \multicolumn{2}{|c|}{$\Rightarrow$ My Workspace: Worksite Setup } \\
\hline \multicolumn{2}{|l|}{ Course Site Tools } \\
\hline \multicolumn{2}{|c|}{ Choose tools to include on your site... } \\
\hline v Home & For viewing recent announcements, discussion, and chat items. \\
\hline$\square$ Announcements & For posting information \\
\hline$\square$ Assignments & For private submission and grading of coursework \\
\hline$\square$ Chat Room & For posting messages among site participants in real time \\
\hline$\square$ Drop Box & For private file sharing between instructors and students \\
\hline$\square$ Email Archive & For displaying email sent to the site \\
\hline$\square$ Engineering Honor Code & For displaying your course honor policy (Engineering courses only) \\
\hline$\square$ Evaluate This Class & For directing students to the Teaching Questionnaire for a class \\
\hline$\square$ Forums & For posting topics and responses \\
\hline$\square$ Gradebook & For posting grades, either entered directly or imported from other tools \\
\hline$\square \quad$ i clicker & Sakai i>clicker Plugin - integrates Sakai and i>clicker products \\
\hline iTunes U & For distributing media using iTunes \\
\hline$\square$ Library Help & For instant-messaging with a UM librarian \\
\hline$\square$ Library Materials & For displaying a list of physical materials on reserve at the UM Libraries \\
\hline
\end{tabular}




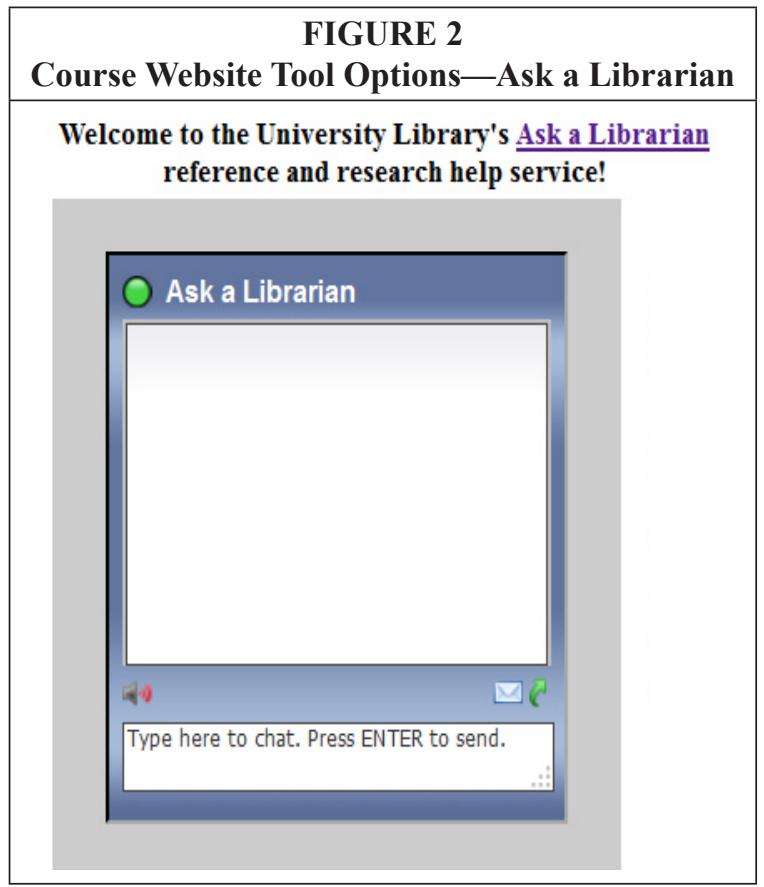

been added to authorize a librarian to read, add, and revise content (see figure 3 ).

This designated Librarian role allows the assigned individual to view the syllabus, post announcements, add resources that are relevant to the course subject and/or research topic, and answer students' questions via e-mail. This unique LMS role was created in 2007 as the result of a request by the university library's Curriculum Integration Coordinator to the LMS administrators, based on substantial interest from librarians to actively participate in their assigned LMS course websites, particularly in regard to the ability to add course-specific content. The Curriculum

Integration Coordinator worked with LMS staff directly to implement this role. While librarians could potentially be added as Affiliates, that role gives access to student grades, which potentially could be of concern to faculty. The new Librarian role does not give librarians access to student grades. However, it allows librarians to interact with students in the course website and answer questions at the time of need, as well as add course-specific content.

Design and functionality issues with the tools themselves were not addressed in this study. While the usability of the LMS site overall and the layout and visibility of the library tools could be improved, these issues were beyond the scope of the present study and were not included in the surveys.

\begin{tabular}{|c|c|}
\hline & $\begin{array}{c}\text { FIGURE } 3 \\
\text { Librarian Role }\end{array}$ \\
\hline \multicolumn{2}{|c|}{ Choose a Role for Participants } \\
\hline Affiliate & Can read, add, and revise content on sites in a particular department. \\
\hline Assistant & Can read, add, and revise most content on the site. \\
\hline Instructor & Can read, revise, delete and add both content and participants to a site. \\
\hline Librarian & Can read, add, and revise most content, cannot see grades. \\
\hline Observer & Can read content on the site. \\
\hline Owner & Can read, revise, delete and add both content and participants to a site. \\
\hline Student & Can read content, and add content to a site where appropriate. \\
\hline
\end{tabular}




\section{Research Methods}

\section{LMS Log Data}

To study the usage of the two library tools (Library Help, Library Materials) and the Librarian role, aggregated system log data for all LMS course websites was analyzed from three semesters: fall 2009, winter 2010 and fall 2010 (see table 1). The LMS system automatically records all user actions with each specific tool, such as posting announcements or downloading documents. These actions are aggregated for each tool by course to capture overall patterns of tool usage. For this study, all LMS course websites that had either library tool turned on and/or a participant assigned to the Librarian role were included in the analysis. Overall, a low percentage of all course websites (an average of $17 \%$ ) had either of the library tools turned on or the Librarian role assigned. The distribution of tool/role usage was similar across the three semesters. The most used library tool for all three semesters was Library Materials (an average of 11.1\%), with Library Help the second most used $(7.9 \%)$ and the Librarian role the least used (3.4\%). Note that more than one library tool can be turned on within a single LMS course website.

Individual LMS course websites with library tools turned on were aggregated the departmental level to determine which departments had the highest overall usage of the library tools each semester. For example, specific courses such as English 124 and English 313 were grouped into "English." Overall, the top combined departments were fairly consistent across the three semesters, with English having the highest overall usage in each term (see table 2).

\begin{tabular}{|l|c|c|c|c|}
\hline \multicolumn{5}{|c|}{ TABLE 1 } \\
\hline & Fall 09 & Winter 10 & Fall 10 & Average \\
\hline All LMS course websites & 4,495 & 4,253 & 4,872 & 4,540 \\
\hline Any tools turned on & 811 & 637 & 873 & 774 \\
\hline Library materials & 588 & 413 & 511 & 504 \\
\hline Library help & 322 & 292 & 464 & 359 \\
\hline Librarian role & 137 & 137 & 198 & 157 \\
\hline
\end{tabular}

\section{TABLE 2}

Top 10 Departments with Library Tools Turned On

\begin{tabular}{|l|c|l|c|l|c|}
\hline \multicolumn{1}{|c|}{ Fall 09 } & Sites & \multicolumn{1}{c|}{ Winter 10 } & Sites & \multicolumn{1}{c|}{ Fall 10 } & Sites \\
\hline English & 71 & English & 76 & English & 84 \\
\hline Social Work & 57 & American Culture & 31 & Social Work & 49 \\
\hline American Culture & 43 & Social Work & 31 & History & 33 \\
\hline Psychology & 38 & Psychology & 30 & Psychology & 32 \\
\hline History & 32 & History & 30 & American Culture & 28 \\
\hline Education & 28 & Sociology & 19 & Sociology & 27 \\
\hline $\begin{array}{l}\text { Cultural } \\
\text { Anthropology }\end{array}$ & 27 & Political Science & 17 & Education & \\
\hline Sociology & 17 & Cultural Anthropology & 16 & Cultural Anthropology & 24 \\
\hline Information & 16 & Afro-American Studies & 16 & Afro-American Studies & 18 \\
\hline Kinesiology & 14 & Nursing & 16 & Asian Studies & 17 \\
\hline
\end{tabular}


Next, the departmental aggregated data were combined into overall totals to determine the top 10 departments with the overall greatest usage of the library tools. These departments were English, Social Work, American Culture, Psychology, History, Cultural Anthropology, Education, Sociology, Afro-American and African Studies, and Political Science. Identifying these departments by organizational unit within the institution shows that 8 of the top 10 are within the College of Literature, Science and the Arts (LSA), the liberal arts division of the university. Two units, Social Work and Education, are separate schools (see table 3).

\begin{tabular}{|l|c|c|}
\hline \multicolumn{3}{|c|}{ TABLE 3} \\
Combined Total Usage for 3 Semesters \\
\hline \multicolumn{1}{|c|}{ Department } & College & $\begin{array}{c}\text { Total } \\
\text { Sites }\end{array}$ \\
\hline English & LSA & 231 \\
\hline Social Work & Social Work & 137 \\
\hline American Culture & LSA & 102 \\
\hline Psychology & LSA & 100 \\
\hline History & LSA & 95 \\
\hline Cultural Anthropology & LSA & 67 \\
\hline Education & Education & 67 \\
\hline Sociology & LSA & 63 \\
\hline Afro-American Studies & LSA & 48 \\
\hline Political Science & LSA & 47 \\
\hline
\end{tabular}

\section{Surveys}

Based on the departments identified as highest use, surveys were created for two groups of faculty: those within these high-use departments who activated the library tools, and those within the same departments who did not. Both surveys asked similar demographic and attitudinal questions, with specific questions customized to the category of use or nonuse of the tools. (For example, users of the library tools were asked: "What functions do you expect the person you assign to the Librarian role to perform?" while nonusers were asked: "If you were to assign a 'Librarian' role in your LMS course website, what functions do you expect the person you assign to the Librarian role to perform?") A third survey was developed for the librarians who used the Librarian role in the LMS to explore the librarian's perspectives and contrast them to the faculty perspectives. See the Appendices for the full text of the surveys.

The surveys were built in the Qualtrics professional online survey tool (www.qualtrics.com) in consultation with the library's Curriculum Integration Coordinator, who is familiar with the LMS and its usage by librarians. The survey contained multiple choice, Likert scale, and open-ended response questions. The user survey contained 21 items, the nonuser survey contained 18 questions, and the librarian survey contained 16 questions. Each survey was designed to identify demographic factors that might affect tool usage and asked respondents questions about awareness of and frequency of use of the library tools and role, perceived usefulness of librarians and the library tools and role, and amount of training received on the tools and role. This study was conducted as part of a broader research program investigating the use of enterprise-level learning technologies in higher education that has been approved and granted exemption from ongoing review from the university's Institutional Review Board for human subjects research.

University human resource records were used to identify faculty in those high-use departments who were not using the tools to compare faculty users and nonusers from within the same departments. Librarians who were associated with the Librarian role were also identified from the LMS logs. Thus, this survey used a purposeful, nonrandom sample to reach all possible participants. E-mail invitations were sent to 1,025 users, 1,686 nonusers, and 52 librarians (2,763 total). Three reminders were sent to all nonrespondents before the survey was closed after one month of data collection. A total of 187 users (18\% response rate), 187 nonusers (11\%), and 30 librarians (57\%) responded to the survey $(\mathrm{N}=404,14 \%$ overall response rate). 


\section{Survey Findings}

Analysis of the survey responses produced the following findings:

- Users reported longer employment as faculty and more expertise with library research vs. nonusers

- Both users and nonusers frequently reported that they were unaware of the existence of the LMS library tools and role.

- Nonusers reported that they were unaware of colleagues in their departments using the library tools and role

- Both faculty groups reported a perceived lack of incentives to use the library tools and role

- Both faculty groups reported positive perceptions of librarians

- Faculty (users and nonusers combined) expressed significantly different expectations of the librarians' role within the LMS than those expressed by librarians

- Both faculty groups reported that their LMS training needs were not being met These results are described below.

A comparison of users' and nonusers' responses to demographic questions revealed significant differences with regard to number of years as an instructor/faculty in higher education $\left(\chi^{2}(5, N=373)=18.046, p=.003\right)$ (see table 4$)$ and overall expertise with library research activities relative to other instructors in their department $\left(\chi^{2}(4, N\right.$ $=370)=19.828, p=.001$ ) (see table 5). Users of the LMS library tools reported longer employment and higher expertise with library research compared to faculty who do not use the LMS tools. Respondents' overall expertise with computers did not produce significant differences between users and nonusers.

\begin{tabular}{|l|c|c|c|c|}
\hline \multicolumn{5}{|c|}{ TABLE 4 } \\
\hline Years of Experience as Instructor/Faculty \\
\hline 1 year or less & Users & $\%$ & Non Users & $\%$ \\
\hline 2-5 years & 5 & $3 \%$ & 19 & $10 \%$ \\
\hline $6-10$ years & 26 & $14 \%$ & 42 & $22 \%$ \\
\hline $11-20$ years & 33 & $18 \%$ & 35 & $19 \%$ \\
\hline 21-30 years & 53 & $28 \%$ & 42 & $22 \%$ \\
\hline More than 30 years & 36 & $19 \%$ & 31 & $17 \%$ \\
\hline Total & 33 & $18 \%$ & 18 & $10 \%$ \\
\hline
\end{tabular}

\begin{tabular}{|l|c|c|c|c|}
\hline \multicolumn{5}{|c|}{ TABLE 5 } \\
Overall Expertise with Library Research \\
\hline Response Option & Users & $\%$ & Non Users & $\%$ \\
\hline Much less experienced & 7 & $4 \%$ & 16 & $9 \%$ \\
\hline Somewhat less experienced & 25 & $14 \%$ & 51 & $27 \%$ \\
\hline About the same experience & 100 & $55 \%$ & 91 & $49 \%$ \\
\hline Somewhat more experienced & 35 & $19 \%$ & 23 & $12 \%$ \\
\hline Much more experienced & 16 & $9 \%$ & 6 & $3 \%$ \\
\hline Total & 183 & $100 \%$ & 187 & $100 \%$ \\
\hline
\end{tabular}




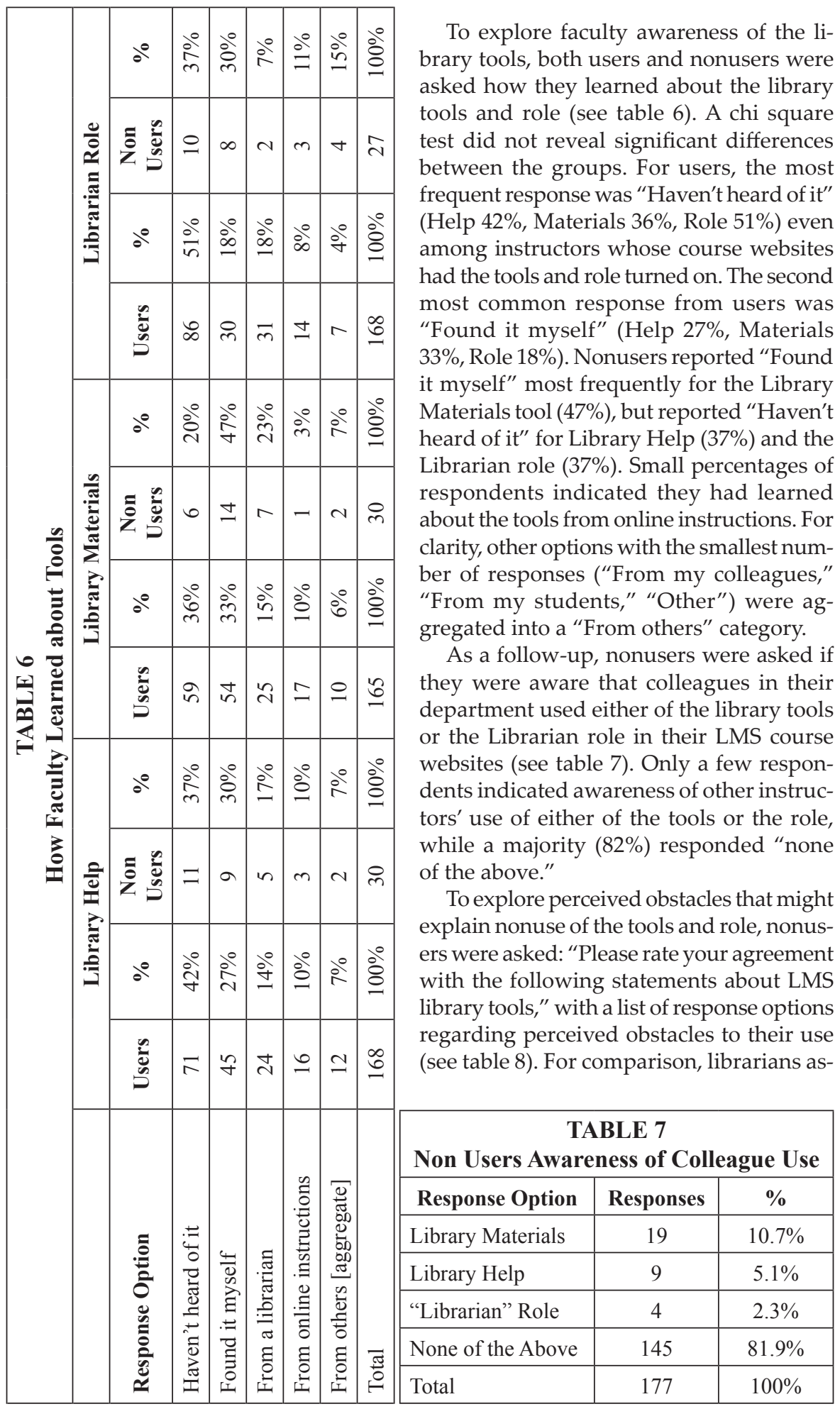




\begin{tabular}{|l|c|c|c|c|}
\hline \multicolumn{7}{|c|}{ TABLE 8 } \\
\hline
\end{tabular}

signed to the Librarian role were asked the same question, to explore whether librarians perceive the same or different reasons for faculty nonuse based on their interactions with faculty. Responses were on a scale of Strongly Disagree (1) to Strongly Agree (5), and means were calculated. An independent samples t-test revealed significant differences between nonusers and librarians for two responses: "Using LMS library tools has little connection to my/instructors course $(s)$ " $(t(207)=3.48, p<.001)$, and "None of my/ instructor's colleagues use the LMS library tools" $(t(201)=2.50, p<.001)$. Although the variations were small, the nonusers agreed more strongly to both responses than did the librarians, suggesting that these concerns are more relevant for faculty. The other response options were not significantly different. The highest combined mean agreement (M=3.1) was with "There is no incentive to use LMS library tools," while the lowest mean agreement was with "LMS library tools are too complicated to learn" $(M=2.4)$.

To explore faculty perceptions of librarians that might impact use of the tools, both users and nonusers were asked: "In terms of helping my students, I consider a librarian to be a valuable resource for..." with a list of response options (see table 9). Responses were on a scale of Strongly Disagree (1) to Strongly Agree (5). An independent samples t-test did not reveal significant differences between faculty groups. Overall, responses were similar, with the choice "Locating library resources" strongly agreed with by both users $(M=4.39)$ and nonusers $(M=4.35)$, followed by "Learning effective information searching techniques" strongly agreed with by both users $(M=4.23)$ and

\section{TABLE 9}

Librarians as a Valuable Resource (Users vs. Non Users)

\begin{tabular}{|l|c|c|c|c|}
\hline Response Option & $\begin{array}{c}\text { User } \\
\text { Mean }\end{array}$ & N & $\begin{array}{c}\text { Non User } \\
\text { Mean }\end{array}$ & N \\
\hline Locating library resources & 4.39 & 163 & 4.35 & 176 \\
\hline Learning effective information searching techniques & 4.23 & 159 & 4.28 & 174 \\
\hline Learning about scholarly databases & 4.36 & 163 & 4.25 & 175 \\
\hline In-person research consultation & 4.25 & 162 & 4.00 & 173 \\
\hline Online/IM chat research questions & 3.61 & 158 & 3.69 & 174 \\
\hline Phone research consultation & 3.43 & 160 & 3.50 & 175 \\
\hline
\end{tabular}


nonusers $(\mathrm{M}=4.28)$. Users showed a slightly stronger agreement for "Learning about scholarly databases" (M=4.36) than nonusers $(M=4.25)$. Online chat reference and phone consultation were the lowest rated by both users and nonusers.

To explore whether differences in perceptions of the role of librarians exist between the respondents, each group was asked a related question with similar response options (see table 10). Faculty users were asked: "What functions do you expect the person you assign to the Librarian role to perform?"; nonusers were asked: "If you were to assign a Librarian role in your LMS course website, what functions do you expect the person you assign to the Librarian role to perform?"; and librarians were asked "What functions did you perform in the Librarian role?" Respondents could choose more than one option ("Check all that apply"). Response options were categorical and not scaled. In evaluating the results, nonresponses were recoded as negative responses, and all faculty responses (user and nonuser) were combined to compare against librarians. Both faculty groups frequently chose "Add library resources to course site" (users $55 \%$, nonusers $73 \%$ ), but librarians chose this item in a much higher percentage (93\%), demonstrating a significantly stronger agreement than faculty $\left(\chi^{2}(1, N=383)=\right.$ $29.250, p<.001)$. "Present in-class about library resources" was chosen by 77 percent of librarians, but only 38 percent of users and 27 percent of nonusers, again showing a significantly higher agreement among librarians than faculty $\left(\chi^{2}(1, N=383)=30.026\right.$, $p<.001)$. "Meet with me/instructor to discuss my/instructor's course" was chosen by 50 percent of librarians, but only 7 percent of users and 23 percent of nonusers $\left(\chi^{2}(1\right.$, $N=383)=30.026, p<.001)$. Overall, these results show that there are significant differences in the perceptions of the role that librarians can play in courses among the survey respondents.

To explore whether LMS training needs were being met, all three groups were asked ("Yes/No") if respondents felt they had received enough training and information on the LMS library tools and role (see table 11). A chi square test did not produce significant differences between the groups. A majority of both groups responded "No" (users $72.6 \%$, nonusers $77.2 \%$ ). In response to "Would you like to receive more information about how to best use the library tools?" significantly more users $(70.3 \%)$ responded

\begin{tabular}{|l|c|c|c|c|c|c|}
\hline \multicolumn{7}{|c|}{ Expected Librarian Role Functions } \\
\hline & Users & $\%$ & $\begin{array}{c}\text { Non } \\
\text { Users }\end{array}$ & $\%$ & Librarians & $\%$ \\
\hline Response Option & 33 & $55 \%$ & 124 & $73 \%$ & 28 & $93 \%$ \\
\hline $\begin{array}{l}\text { Add library resources to course } \\
\text { website }\end{array}$ & 15 & $25 \%$ & 28 & $17 \%$ & 9 & $30 \%$ \\
\hline $\begin{array}{l}\text { Answer questions from students in } \\
\text { person }\end{array}$ & 34 & $57 \%$ & 118 & $70 \%$ & 15 & $50 \%$ \\
\hline $\begin{array}{l}\text { Answer questions from students } \\
\text { online }\end{array}$ & 7 & $12 \%$ & 39 & $23 \%$ & 15 & $50 \%$ \\
\hline $\begin{array}{l}\text { Meet with me/instructor to discuss } \\
\text { my course }\end{array}$ & 23 & $38 \%$ & 45 & $27 \%$ & 23 & $77 \%$ \\
\hline $\begin{array}{l}\text { Present in-class about library } \\
\text { resources }\end{array}$ & 8 & $13 \%$ & 44 & $26 \%$ & 7 & $23 \%$ \\
\hline $\begin{array}{l}\text { Work with me/instructor to develop } \\
\text { a research assignment }\end{array}$ & 60 & & 169 & & 30 & \\
\hline Total respondents & & & & & & \\
\hline
\end{tabular}




\begin{tabular}{|c|c|c|c|c|c|c|c|c|c|}
\hline \multicolumn{10}{|c|}{$\begin{array}{c}\text { TABLE } 11 \\
\text { Training Needs }\end{array}$} \\
\hline \multirow[b]{2}{*}{ Response Option } & \multicolumn{3}{|c|}{ Users } & \multicolumn{3}{|c|}{ Non Users } & \multicolumn{3}{|c|}{ Librarians } \\
\hline & Yes & No & $\mathbf{N}$ & Yes & No & $\mathbf{N}$ & Yes & No & $\mathbf{N}$ \\
\hline $\begin{array}{l}\text { Received adequate information } \\
\text { training related to the LMS library } \\
\text { tools? }\end{array}$ & 45 & 119 & 164 & 41 & 139 & 180 & 8 & 18 & 26 \\
\hline $\begin{array}{l}\text { Like to receive more information } \\
\text { about how to best use the library } \\
\text { tools? }\end{array}$ & 116 & 49 & 165 & 107 & 72 & 179 & $\mathrm{n} / \mathrm{a}$ & $\mathrm{n} / \mathrm{a}$ & $\mathrm{n} / \mathrm{a}$ \\
\hline
\end{tabular}

"Yes" than nonusers (59.8\%), suggesting that faculty who already use the tool would like more training $\left(\chi^{2}(1, N=344)=4.172, p=.041\right)$. Librarians were asked a parallel question: "Do you feel that faculty members receive adequate information/training related to the LMS library tools?" with 69.2 percent responding "No." Overall, all three groups strongly agreed that more training in the use of the LMS library tools was required.

\section{Discussion}

In this study, log data was used to determine the frequency of use of the LMS library tools and Librarian role, as well as the academic departments that accounted for the greatest usage. Overall, a low percentage of all LMS course sites (an average of $17.0 \%$ ) had either of the library tools or role turned on. The usage of the two library tools and the Librarian role was similar across the three semesters, with the most used tool for all three semesters being Library Materials (an average of $11.1 \%$ ), followed by Library Help (7.9\%) and the Librarian role (3.4\%). In response to RQ 1 ("Which departments have the highest usage of the library tools?"), results showed that the majority of the high-use departments are in the LSA (Literature, Science, and the Arts) college, with English being the top department, possibly because those departments tend to assign research papers that require using scholarly databases and citing credible sources for which students may need library help.

Survey responses were used to determine if there were demographic differences between users and nonusers that might correlate with usage and also to gather responses about awareness and perceptions of the library tools and role that might affect adoption and usage. In response to RQ2 ("Are there significant differences between faculty users and nonusers of the tools?"), users reported longer employment as faculty and higher overall expertise with library research versus nonusers. These results suggest that more experienced faculty are more likely to find and use the LMS library tools. It also suggests that departments where faculty are likely to require library research assignments may also be more likely to have greater numbers of library tool users.

Overall, basic awareness of the LMS library tools and role and their function proved to be extremely low. The most frequent response about the tools from both users and nonusers was "Haven't heard of it," even among instructors whose course websites had the tools turned on. Possible explanations for this apparent contradiction are that faculty may have turned on the tool unintentionally, may have forgotten about it by the time class was underway, or that course websites were created by student assistants or other support staff rather than by the instructor of record. A majority of nonusers were also not aware that colleagues in their own department used the library tools in their LMS course websites. Greater institutionwide and departmentwide publicity of the availability and benefits of the tools would likely help increase awareness and usage. Faculty also showed a lack of understanding of the value of the tools in their 
courses. Although nonusers frequently responded that they would expect a librarian to add resources to their course website (if they used one) and to answer questions from students online, they also most frequently agreed that "Using LMS library tools has little connection to my course(s)." Thus, nonusers express value for the exact services that the library tools offer, without being aware that they are available through the LMS. This represents an opportunity for librarians to champion the LMS library tools and inform faculty of their value.

In response to RQ3 ("How do faculty perceptions of library resources and functions in the LMS differ from those of librarians?"), faculty strongly agreed that "Locating library resources" was a highly valued librarian role, and librarians agreed that "Add library resources to course website" was an expected librarian role. These perceptions correlate to high awareness of the "Library Materials" tool, which is by far the most used tool. However, some significant differences also emerged. Librarians placed much greater emphasis on "Present in class about library resources" and "Meet with instructor to discuss instructor's course" than faculty, who emphasized the practical options of adding resources and answering student questions. These differing expectations may form an unspoken misunderstanding between librarians and faculty over the librarian's role in a course. Integration of the library presence into LMS course websites presents an option for librarians to achieve their goal of interacting with classes in a format that may match more closely to instructors' expectations.

While faculty indicated that "Answer questions from students online" was an expected function of the Librarian role, they did not choose "Online/Instant Message (IM) chat research questions" as a particularly valuable resource provided by librarians. Perhaps faculty do not understand what an IM chat reference service provides, or they do not personally value online question answering but perceive it as valuable to students. Most faculty are also not aware of the existence of the Library Help tool (IM chat widget) that offers this function embedded within the LMS. This suggests that it may be effective for librarians to promote the online question answering functionality of the library tools, since this tool meets a stated need of faculty and is easily integrated into course websites. Better training on the functions of the LMS library tools and how they can benefit teaching and learning may help increase faculty usage.

Overall, faculty respondents (both users and nonusers) displayed a very positive opinion of librarians. The potential exists for librarians to lead the way in demonstrating the value of integrating the tools into course websites. Some practical approaches to increasing awareness of the library tools include making them more visible and user-friendly by renaming them to make their function more obvious (for instance, "Ask a Librarian" vs. "Library Help" and "Course Reserves" vs. "Library Materials"). Another approach is to focus outreach efforts on instructors in the College of LSA, particularly in English, social science, and humanities departments, where the greatest use of the tools exists and where instructors' assignments may more likely involve library research. Libraries could consider targeting outreach regarding the LMS library tools to more experienced instructors who may be more aware of the tools. An EDUCAUSE research report found that the influence of peers' recommending the use of a LMS or setting an example of use is especially important in encouraging adoption among faculty. ${ }^{35}$ However, peer awareness was the least frequently chosen response to the question "How did you learn about the library tools?" in the survey, suggesting a need for library staff to enlist current users of the tools to spread the word among their colleagues. Libraries could best leverage their limited promotional resources toward faculty in departments who are the most likely to be receptive to adoption of the tools, as there are already allies among them who are users of the tools and can provide peer recommendations and support. 
Addressing the training needs clearly expressed by the survey respondents is also critical. Both users and nonusers responded that they had not received enough training and they would like to receive more information. Several approaches could be taken to address this issue. Subject librarians with existing relationships to academic departments could be enlisted to promote the availability of training. To encourage faculty participation in trainings, and to address the perceived lack of incentives to use the library tools, college deans and administrators could be involved in promoting the training and in communicating their benefits to their faculty. The EDUCAUSE report also found that influence of departmental or administrative leadership was important to encourage faculty usage by providing incentives through establishing departmental standards and spreading awareness. ${ }^{36}$ Focusing library promotion at the department level, targeted toward departments that already use the tools and role, could help encourage reluctant faculty.

Lack of awareness, coupled with lack of incentives and the need for training, makes for a serious set of obstacles to faculty adoption and usage of the library tools. The recommendations above are a starting point for further exploration into potential solutions. Both librarians and instructors might benefit from exploratory focus groups that could examine intersections between technology requirements, faculty needs, and librarian expertise with the goal of identifying possible new approaches and new functionality within the LMS. Recently, the library at this institution introduced two new LMS tools: "Library Search," which allows users to search the catalog and articles databases; and "Research Guide," which allows instructors to automatically link to a subject-relevant research guide developed by a librarian. Usage data shows that neither tool is widely used, reinforcing the need for increased awareness, training, and incentives.

Future research could also investigate how students perceive LMS library tools, and the effect on student learning of integrating library resources and services into LMSs. Have student perceptions of the library changed as embedded librarians have worked to integrate library resources into LMS course websites, rather than waiting for students to come to them? How does connecting with students at their point of need through embedded LMS library tools impact their research habits? As students increasingly rely on online information sources, integrating library services directly into the course infrastructure becomes increasingly important. Providing "just in time" and "point of need" assistance to students can help those students see greater relevance of library resources. Research into the impact of this strategic, contextualized placement of library resources can help determine how librarians can better meet the needs of 21st-century learners.

\section{Acknowledgments}

Thanks to Susan Hollar, Curriculum Integration Coordinator in the University Library at the University of Michigan for her support in conducting this study. 


\section{Appendix. LMS Library Tools Survey}

\section{Version for Faculty Who Have Used the Tools}

Note: The name of the specific LMS has been removed from the survey texts.

Q1. How many years have you been an instructor/faculty in higher education?
O 1 year or less
O 2-5 years
O 6-10 years
11-20 years
O 21-30 years
O More than 30 years

Q2. Rate your overall expertise with computers relative to other instructors in your department:

O Much less experienced

Somewhat less experienced

O About the same experience

Somewhat more experienced

Much more experienced

Q3. Rate your overall expertise with library research activities relative to other instructors in your department:

O Much less experienced

Somewhat less experienced

O About the same experience

O Somewhat more experienced

O Much more experienced

Q4. The LMS has three library-related tools that are designed to support your students' library research. Please answer the questions below for the tools that you have used: 1) The "Library Help" tool allows students to virtually chat (in other words, Instant Message) with a librarian.

\begin{tabular}{|l|c|c|c|c|c|c|}
\hline & $\begin{array}{c}\text { Strongly } \\
\text { Disagree }\end{array}$ & Disagree & $\begin{array}{c}\text { Neither Agree } \\
\text { Nor Disagree }\end{array}$ & Agree & $\begin{array}{c}\text { Strongly } \\
\text { Agree }\end{array}$ & $\begin{array}{c}\text { Have Not } \\
\text { Used }\end{array}$ \\
\hline $\begin{array}{l}\text { This tool has } \\
\text { been useful in } \\
\text { my course(s) }\end{array}$ & $\bigcirc$ & $\bigcirc$ & $\bigcirc$ & $\bigcirc$ & $\bigcirc$ & $\bigcirc$ \\
\hline
\end{tabular}

Q5. 2) The "Library Materials" tool automatically links to any course materials you have on reserve in the UM library.

\begin{tabular}{|l|c|c|c|c|c|c|}
\hline & $\begin{array}{c}\text { Strongly } \\
\text { Disagree }\end{array}$ & Disagree & $\begin{array}{c}\text { Neither Agree } \\
\text { Nor Disagree }\end{array}$ & Agree & $\begin{array}{c}\text { Strongly } \\
\text { Agree }\end{array}$ & $\begin{array}{c}\text { Have Not } \\
\text { Used }\end{array}$ \\
\hline $\begin{array}{l}\text { This tool has } \\
\text { been useful in } \\
\text { my course(s) }\end{array}$ & $\bigcirc$ & $\bigcirc$ & $\bigcirc$ & $\bigcirc$ & $\bigcirc$ & $\bigcirc$ \\
\hline
\end{tabular}

Q6. 3) The "Librarian" role allows you to assign a user who will have access to your LMS course site to post announcements, add resources, answer questions, etc.

\begin{tabular}{|l|c|c|c|c|c|c|}
\hline & $\begin{array}{c}\text { Strongly } \\
\text { Disagree }\end{array}$ & Disagree & $\begin{array}{c}\text { Neither Agree } \\
\text { Nor Disagree }\end{array}$ & Agree & $\begin{array}{c}\text { Strongly } \\
\text { Agree }\end{array}$ & $\begin{array}{c}\text { Have Not } \\
\text { Used }\end{array}$ \\
\hline $\begin{array}{l}\text { This tool has } \\
\text { been useful in } \\
\text { my course(s) }\end{array}$ & $\bigcirc$ & $\bigcirc$ & $\bigcirc$ & $\bigcirc$ & $\bigcirc$ & $\bigcirc$ \\
\hline
\end{tabular}


Q7. In a typical semester, how often do you visit your LMS course site(s)? Please select one:

O Never

A few times a semester

A few times a month

A few times a week

O Daily

Q8. How did you learn about the library tools in the LMS course sites?

\begin{tabular}{|l|c|c|c|c|c|c|c|}
\hline & $\begin{array}{c}\text { Found } \\
\text { It } \\
\text { Myself }\end{array}$ & $\begin{array}{c}\text { From a } \\
\text { Librarian }\end{array}$ & $\begin{array}{c}\text { From } \\
\text { Colleagues }\end{array}$ & $\begin{array}{c}\text { From LMS } \\
\text { Online } \\
\text { Instructions }\end{array}$ & $\begin{array}{c}\text { From My } \\
\text { Students }\end{array}$ & Other & $\begin{array}{c}\text { Haven't } \\
\text { Heard } \\
\text { of It }\end{array}$ \\
\hline Library Help & $\bigcirc$ & $\bigcirc$ & $\bigcirc$ & $\bigcirc$ & $\bigcirc$ & $\bigcirc$ & $\bigcirc$ \\
\hline $\begin{array}{l}\text { Library } \\
\text { Materials }\end{array}$ & $\bigcirc$ & $\bigcirc$ & $\bigcirc$ & $\bigcirc$ & $\bigcirc$ & $\bigcirc$ & $\bigcirc$ \\
\hline $\begin{array}{l}\text { "Librarian" } \\
\text { Role }\end{array}$ & $\bigcirc$ & $\bigcirc$ & $\bigcirc$ & $\bigcirc$ & $\bigcirc$ & $\bigcirc$ & $\bigcirc$ \\
\hline
\end{tabular}

Answer If Q8-Other Is Selected

Q9. If "Other," please describe:

Q10. Do you give your students an overall introduction to the tools available on your LMS course site?

Y Yes

O No

Answer If Q10-Yes Is Selected:

Q11. Do you give your students an introduction to the library-related tools on your LMS course site?

Yes

$\mathrm{O}$ No

Answer If Q11 - Yes Is Selected:

Q12. When you give your students an introduction to the library tools, what tools do you cover?

Library Help

L Library Materials

O "Librarian" role

Answer If Q6-Have Not Used Is Not Selected:

Q13. The person to whom you assign to the "Librarian" role in your LMS course site is most likely to be:

O GSI

Student in my class

O UM librarian

Other (please describe their position/job)

Answer if Q6-Have Not Used Is Not Selected:

Q14. What functions do you expect the person you assign to the "Librarian" role to perform? (Check all that apply)

O Add library resources to course site

Answer questions from students in person

Answer questions from students online

Meet with me to discuss my course

Present in-class about library resources

O Work with me to develop a research assignment

Other (please describe): 
Q15. In terms of helping my students, I consider a librarian to be a valuable resource for:

\begin{tabular}{|l|c|c|c|c|c|}
\hline & $\begin{array}{c}\text { Strongly } \\
\text { Agree }\end{array}$ & Agree & $\begin{array}{c}\text { Neither Agree } \\
\text { Nor Disagree }\end{array}$ & Disagree & $\begin{array}{c}\text { Strongly } \\
\text { Disagree }\end{array}$ \\
\hline In-person research consultation & $\bigcirc$ & $\bigcirc$ & $\bigcirc$ & $\bigcirc$ & $\bigcirc$ \\
\hline $\begin{array}{l}\text { Learning about scholarly } \\
\text { databases }\end{array}$ & $\bigcirc$ & $\bigcirc$ & $\bigcirc$ & $\bigcirc$ & $\bigcirc$ \\
\hline $\begin{array}{l}\text { Learning effective information } \\
\text { searching techniques }\end{array}$ & $\bigcirc$ & $\bigcirc$ & $\bigcirc$ & $\bigcirc$ & $\bigcirc$ \\
\hline Locating library resources & $\bigcirc$ & $\bigcirc$ & $\bigcirc$ & $\bigcirc$ & $\bigcirc$ \\
\hline $\begin{array}{l}\text { Online/IM chat research } \\
\text { questions }\end{array}$ & $\bigcirc$ & $\bigcirc$ & $\bigcirc$ & $\bigcirc$ & $\bigcirc$ \\
\hline Phone research consultation & $\bigcirc$ & $\bigcirc$ & $\bigcirc$ & $\bigcirc$ & $\bigcirc$ \\
\hline
\end{tabular}

Q16. Do you feel you received adequate information/training related to the LMS library tools?

$\mathrm{O}$ Yes

O No

Q17. Would you like to receive more information about how to best utilize the library tools?

O Yes

O No

Answer If Q17-Yes Is Selected:

Q18. For any future training(s), what format would be most useful?

O Instructions via email

One-on-one consultation

O Online documentation

Tutorial video

Other (please describe):

Q19. What is the most important improvement you would make to the existing LMS library tools?

Q20. What new library-related functionality or tool would you like to see added to the LMS?

Q21. Do you have any other comments on your experience with the LMS library tools?

\section{Version for Faculty Who Have Not Used the Tools}

Q1. How many years have you been an instructor/faculty in higher education?

O 1 year or less

2-5 years

6-10 years

O 11-20 years

O 21-30 years

O More than 30 years

Q2. Rate your overall expertise with computers relative to other instructors in your department:

Much less experienced

Somewhat less experienced

O About the same experience

O Somewhat more experienced

Much more experienced 
Q3. Rate your overall expertise with library research activities relative to other instructors in your department:

Much less experienced

O Somewhat less experienced

O About the same experience

Somewhat more experienced

Much more experienced

Q4. Do you currently use a LMS course site?

O Yes

O No

Q5. In previous semesters, have you used a LMS course site?

O Yes

O No

Answer If Q4-Yes Is Selected Or Q5-Yes Is Selected

Q6. In a typical semester, how often do you visit your LMS course site(s)? Please select one:

O Never

O A few times a semester

A few times a month

O A few times a week

Daily

Q7. The LMS has three library-related tools that are designed to support your students' library research. 1) The "Library Help" tool allows students to virtually chat (in other words, Instant Message) with a librarian 2) The "Library Materials" tool automatically links to any course materials you have on reserve in the UM library. 3)"The "Librarian" role allows you to assign a user who will have access to your course site to post announcements, add resources, answer questions, and so on. Which of these tools are you familiar with?

Library Help

Library Materials

O "Librarian" Role

None of the Above

Answer if Q7-None of the Above Is Not Selected

Q8 How did you learn about the library tool(s) in LMS course sites?

\begin{tabular}{|l|c|c|c|c|c|c|c|}
\hline & $\begin{array}{c}\text { Found It } \\
\text { Myself }\end{array}$ & $\begin{array}{c}\text { From a } \\
\text { Librarian }\end{array}$ & $\begin{array}{c}\text { From } \\
\text { Colleagues }\end{array}$ & $\begin{array}{c}\text { From LMS } \\
\text { Online } \\
\text { Instructions }\end{array}$ & $\begin{array}{c}\text { From } \\
\text { my } \\
\text { Students }\end{array}$ & Other & $\begin{array}{c}\text { Not } \\
\text { Applicable }\end{array}$ \\
\hline $\begin{array}{l}\text { Library } \\
\text { Help }\end{array}$ & $\bigcirc$ & $\bigcirc$ & $\bigcirc$ & $\bigcirc$ & $\bigcirc$ & $\bigcirc$ & $\bigcirc$ \\
\hline $\begin{array}{l}\text { Library } \\
\text { Materials }\end{array}$ & $\bigcirc$ & $\bigcirc$ & $\bigcirc$ & $\bigcirc$ & $\bigcirc$ & $\bigcirc$ & $\bigcirc$ \\
\hline $\begin{array}{l}\text { "Librarian" } \\
\text { Role }\end{array}$ & $\bigcirc$ & $\bigcirc$ & $\bigcirc$ & $\bigcirc$ & $\bigcirc$ & $\bigcirc$ & $\bigcirc$ \\
\hline
\end{tabular}

Answer If Q8-Other Is Selected

Q9. If "Other," please describe: 
Q10. Please rate your agreement with the following statements about the LMS library tools:

\begin{tabular}{|c|c|c|c|c|c|}
\hline & $\begin{array}{l}\text { Strongly } \\
\text { Disagree }\end{array}$ & Disagree & $\begin{array}{l}\text { Neither } \\
\text { Agree Nor } \\
\text { Disagree }\end{array}$ & Agree & $\begin{array}{l}\text { Strongly } \\
\text { Agree }\end{array}$ \\
\hline $\begin{array}{l}\text { Learning how to use the LMS } \\
\text { library tools is too time } \\
\text { consuming for me }\end{array}$ & 0 & 0 & 0 & 0 & 0 \\
\hline $\begin{array}{l}\text { The LMS library tools are too } \\
\text { complicated for me to learn }\end{array}$ & 0 & 0 & 0 & 0 & 0 \\
\hline $\begin{array}{l}\text { There is no incentive to use LMS } \\
\text { library tools }\end{array}$ & 0 & 0 & 0 & 0 & 0 \\
\hline $\begin{array}{l}\text { Using LMS library tools has little } \\
\text { connection to my course(s) }\end{array}$ & 0 & 0 & 0 & 0 & 0 \\
\hline $\begin{array}{l}\text { I need greater technical support } \\
\text { to use LMS library tools in my } \\
\text { course(s) }\end{array}$ & 0 & 0 & 0 & 0 & 0 \\
\hline $\begin{array}{l}\text { None of my colleagues use LMS } \\
\text { library tools }\end{array}$ & 0 & 0 & 0 & 0 & 0 \\
\hline
\end{tabular}

Q11. Some faculty members in your department use the library help tools in their LMS course sites. Which tool(s) are you aware that your colleagues use?

Library Help

Library Materials

O "Librarian" Role

None of the Above

Q12. If you were to assign a "Librarian" role in your LMS course site, what functions would you expect that person to perform? (Check all that apply)

Add library resources to course site

Answer questions from students in person

Answer questions from students online

O Meet with me to discuss your course

O Present in class about library resources

Work with me to develop a research assignment

Other (please describe):

Q13. In terms of helping my students, I consider a librarian to be a valuable resource for:

\begin{tabular}{|l|c|c|c|c|c|}
\hline & $\begin{array}{c}\text { Strongly } \\
\text { Agree }\end{array}$ & Agree & $\begin{array}{c}\text { Neither Agree } \\
\text { Nor Disagree }\end{array}$ & Disagree & $\begin{array}{c}\text { Strongly } \\
\text { Disagree }\end{array}$ \\
\hline In-person research consultation & $\bigcirc$ & $\bigcirc$ & $\bigcirc$ & $\bigcirc$ & $\bigcirc$ \\
\hline $\begin{array}{l}\text { Learning about scholarly } \\
\text { databases }\end{array}$ & $\bigcirc$ & $\bigcirc$ & $\bigcirc$ & $\bigcirc$ & $\bigcirc$ \\
\hline $\begin{array}{l}\text { Learning effective information- } \\
\text { searching techniques }\end{array}$ & $\bigcirc$ & $\bigcirc$ & $\bigcirc$ & $\bigcirc$ & $\bigcirc$ \\
\hline Locating library resources & $\bigcirc$ & $\bigcirc$ & $\bigcirc$ & $\bigcirc$ & $\bigcirc$ \\
\hline $\begin{array}{l}\text { Online/IM chat research } \\
\text { questions }\end{array}$ & $\bigcirc$ & $\bigcirc$ & $\bigcirc$ & $\bigcirc$ & $\bigcirc$ \\
\hline Phone research consultation & $\bigcirc$ & $\bigcirc$ & $\bigcirc$ & $\bigcirc$ & $\bigcirc$ \\
\hline
\end{tabular}


Q14. Do you feel you received adequate information/training related to the LMS library tools?

O Yes

O No

Q15. Would you like to receive more information about how to best use the library tools?

$O$ Yes

O No

Answer Q15-Yes Is Selected

Q16. For any future training(s), what format would be most useful?

O Instructions via e-mail

One-on-one consultation

Online documentation

Tutorial video

Other (please describe):

Q17. What new library-related functionality or tool would you like to see added to the LMS?

Q18. Do you have any other comments on the LMS library tools?

\section{Version for Librarians}

Q1. How would you rate your satisfaction with your experience of the "Librarian" role?

Very Satisfied

O Satisfied

O Neutral

O Dissatisfied

Very Dissatisfied

Q2. Who initiated contact regarding assigning you to the "Librarian" role in the LMS?

O Self

Instructor(s)

Graduate Student Instructor(s)

Other

Q3. Please describe your overall experience with the LMS “Librarian" role:

Q4. Did the instructor(s) typically provide you with direction regarding their needs/ expectations for the course?

O Yes

O No

O Answer If Q5-Yes Is Selected

Q5. Please describe the direction that you received from the instructor(s):

Q6. How frequently did you typically interact with the course instructor(s)?

O Never

A few times a semester

A few times a month

O A few times a week

Daily

Q7. What functions did you perform in the "Librarian" role? (Check all that apply)

O Add library resources to course site

Answer questions from students in person

Answer questions from students online

Meet with instructor to discuss their course(s)

O Present in class about library resources

Work with instructor(s) to develop a research assignment

Other (please describe): 
Q8. When you are assigned a "Librarian" role, how frequently do you access the LMS site(s) for the course?
O Never
A few times a semester
A few times a month
O few times a week
O Daily

Q9. Do you feel that faculty members receive adequate information/training related to the LMS library tools?

O Yes

O No

Answer If Q10-No Is Selected

Q10. For any future instructor training on the LMS library help tools, what format would be most useful?

O Instructions via e-mail

O One-on-one consultation

O Online documentation

O Tutorial video

Other (please describe):

Q11. Please rate your agreement with the following statements about some instructors' potential barriers for using the LMS library tools:

\begin{tabular}{|c|c|c|c|c|c|}
\hline & $\begin{array}{l}\text { Strongly } \\
\text { Disagree }\end{array}$ & Disagree & $\begin{array}{l}\text { Neither } \\
\text { Agree Nor } \\
\text { Disagree }\end{array}$ & Agree & $\begin{array}{l}\text { Strongly } \\
\text { Agree }\end{array}$ \\
\hline $\begin{array}{l}\text { Learning how to use the LMS } \\
\text { library tools is too time } \\
\text { consuming for instructors }\end{array}$ & 0 & 0 & 0 & 0 & 0 \\
\hline $\begin{array}{l}\text { The LMS library tools are too } \\
\text { complicated for instructors to learn }\end{array}$ & 0 & 0 & 0 & 0 & 0 \\
\hline $\begin{array}{l}\text { There is no incentive for instructors } \\
\text { to use the LMS library tools }\end{array}$ & 0 & 0 & 0 & 0 & 0 \\
\hline $\begin{array}{l}\text { Using the LMS library tools has } \\
\text { little connection to instructors' } \\
\text { course(s) }\end{array}$ & 0 & 0 & 0 & 0 & 0 \\
\hline $\begin{array}{l}\text { Instructors need greater technical } \\
\text { support to use the LMS library } \\
\text { tools in their course(s) }\end{array}$ & 0 & 0 & 0 & 0 & 0 \\
\hline $\begin{array}{l}\text { None of instructors' colleagues use } \\
\text { the LMS library tools }\end{array}$ & 0 & 0 & 0 & 0 & 0 \\
\hline
\end{tabular}

Q12. The following questions will ask you about your general perceptions related to the LMS library tools, overall: What is the most important improvement you would make to the existing the LMS library tools?

Q13. What new library-related functionality or tool would you like to see added to the LMS?

Q14. Do you have any other comments on your experience with the LMS library tools? 


\section{Notes}

1. William H. Dutton, Pauline H. Cheong, and Namkee Park, "The Social Shaping of a Virtual Learning Environment: The Case of a University-Wide Course Management System," Electronic Journal of e-Learning 2, no. 1 (2004): 69-80; Judy Xiao, "Integrating Information Literacy Into Blackboard: Librarian-Faculty Collaboration for Successful Student Learning," Library Management 31, no. 8/9 (2010): 654-68; John D. Shank and Nancy H. Dewald, "Establishing Our Presence in Courseware: Adding Library Services to the Virtual Classroom," Information Technology and Libraries 22, no. 1 (2003):38-43.

2. Stephanie D. Teasley and Steven Lonn, “Using Learning Management Systems to Support Students' Collaborative Learning in Higher Education," in Proceedings of the 8th International Conference on Computer Supported Collaborative Learning (CSCL'07), eds. Clark A. Chinn, Gijsbert Erkens, and Sadhana Puntambeka (New Brunswick, N.J.: International Society of the Learning Sciences, 2007): 718-20; Steven Lonn, Stephanie D. Teasley, and Andrew E. Krumm, "Who Needs to Do What Where? Using Learning Management Systems on Residential vs. Commuter Campuses," Computers \& Education 56, no. 3 (Apr. 2011): 642-49; Steven Lonn and Stephanie D. Teasley, "Saving Time or Innovating Practice: Investigating Perceptions and Uses of Learning Management Systems," Computers and Education 53, no. 3 (2009): 686-94.

3. Steven J. Bell and John D. Shank, "Linking the Library to Courseware: A Strategic Alliance to Improve Learning Outcomes," Library Issues 25, no. 2 (2004): 1-4; Elizabeth L. Black and Betsy L. Blankenship, "Linking Students to Library Resources through the Learning Management System," Journal of Library Administration 50, no. 5 (2010): 458-67; Elizabeth L. Black, "Toolkit Approach to Integrating Library Resources into the Learning Management System," Journal of Academic Librarianship 34, no. 6 (2008): 496-501; Bernd W. Becker, "Embedded Librarianship: A Point-of-Need Service," Behavioral \& Social Sciences Librarian 29, no. 3 (2010): 237-40.

4. Teasley and Lonn, "Using Learning Management Systems to Support Students' Collaborative Learning in Higher Education," 718; Lonn, Teasley, and Krumm, "Who Needs to Do What Where?" 642.

5. Shank and Dewald, "Establishing Our Presence in Courseware," 38-43; Dorothy Barr, "Reaching Students Where They Go: Embedding Library Resources in Course Content," Science \& Technology Libraries 29, no. 4 (2010): 289-97.

6. Emily Daly, "Instruction Where and When Students Need It: Embedding Library Resources into Learning Management Systems," eds. C. Kvenild \& K. Calkins, Embedded Librarians: Moving Beyond One-Shot Instruction (Chicago, Ill.: Association of College \& Research Libraries, 2011): 79-91; Barr, "Reaching Students Where They Go," 296.

7. Pamela Alexondra Jackson, "Integrating Information Literacy into Blackboard: Building Campus Partnerships for Successful Student Learning," Journal of Academic Librarianship 33, no. 4 (July 2007): 454-61.

8. Xiao, "Integrating Information Literacy into Blackboard," 666; Bell and Shank, "Linking the Library to Courseware," 4.

9. Amy C. York and Jason M. Vance, “Taking Library Instruction into the Online Classroom: Best Practices for Embedded Librarians," Journal of Library Administration 49, no. 1/2 (2009): 197-209; Jackson, "Integrating Information Literacy into Blackboard,"455; Bell and Shank, "Linking the Library to Courseware," 3; Lori S. Mestre, Lisa Baures, Mona Niedbala, Corinne Bishop, Sarah Cantrell, Alice Perez, and Kate Silfen, "Learning Objects as Tools for Teaching Information Literacy Online: A Survey of Librarian Usage," College and Research Libraries 72, no. 3 (2011): 236-52; Mestre et al., "Learning Objects as Tools for Teaching Information Literacy Online," 243; Kara L. Giles, "Reflections on a Privilege: Becoming Part of the Course through a Collaboration on Blackboard," College and Research Libraries News 65, no. 5 (2004): 261-68.

10. Sheila Corrall and Jonathan Keates, "The Subject Librarian and the Virtual Learning Environment: A Study of UK Universities," Program: Electronic Library and Information Systems 45, no. 1 (2011): 29-49; Bell and Shank, "Linking the Library to Courseware," 2.

11. Oya Y. Rieger, Angela K. Horne, and Ira Revels, "Linking Course Web Sites to Library Collections and Services," Journal of Academic Librarianship 30, no. 3 (May 2004): 205-11; Shank and Dewald, "Establishing Our Presence in Courseware," 42.

12. Marianne A. Buehler, "Where Is the Library in Course Management Software?" Journal of Library Administration 41, no. 1/2 (2004): 75-84; Bell and Shank, "Linking the Library to Courseware," 2; York and Vance, "Taking Library Instruction into the Online Classroom," 197-209; Shank and Dewald, "Establishing Our Presence in Courseware," 38; Jackson, "Integrating Information Literacy into Blackboard," 455.

13. York and Vance, "Taking Library Instruction into the Online Classroom," 197; Amy Schroeder, "Replacing Face-to-Face Information Literacy Instruction: Offering the Embedded 
Librarian Program to All Courses," eds. C. Kvenild and K. Calkins, Embedded Librarians: Moving beyond One-Shot Instruction (Chicago, Ill.: Association of College \& Research Libraries, 2011): 63-78; A.J. Head and M.B. Eisenberg, "Truth Be Told: How College Students Evaluate and Use Information in the Digital Age: Project Information Literacy Progress Report," available online at www.projectinfolit.org/pdfs/PIL_Fall2010_Survey_FullReport1.pdf [accessed 1 March 2014]; Steven J. Bell and John Shank, "The Blended Librarian: A Blueprint for Redefining the Teaching and Learning Role of Academic Librarians," College E Research Libraries News 65, no. 7 (July 6, 2004): 372-75; Rieger, Horne, and Revels, "Linking Course Web Sites to Library Collections and Services," 205.

14. Becker, "Embedded Librarianship," 237; Schroeder, "Replacing Face-to-Face Information Literacy Instruction," 63.

15. York and Vance, "Taking Library Instruction into the Online Classroom," 199; Barr, "Reaching Students Where They Go," 296.

16. Becker, "Embedded Librarianship," 239.

17. Chad Mairn, "Enhancing Learning While Creating a Library Presence in Course Management Systems," Journal of Web Librarianship 4, no. 1 (2010): 55-61; York and Vance, "Taking Library Instruction into the Online Classroom," 198; Rieger, Horne, and Revels, "Linking Course Web Sites to Library Collections and Services," 205; Shank and Dewald, "Establishing Our Presence in Courseware," 42; Lynda M. Kellam, Richard Cox, and Hannah Winkler, "Hacking Blackboard: Customizing Access to Library Resources through the Blackboard Course Management System," Journal of Web Librarianship 3, no. 4 (2009): 349-63.

18. Black and Blankenship, "Linking Students to Library Resources through the Learning Management System," 466.

19. Barr, "Reaching Students Where They Go," 296.

20. Barbara Costello, Robert Lenholt, and Judson Stryker, "Using Blackboard in Library Instruction: Addressing the Learning Styles of Generations X and Y," Journal of Academic Librarianship 30, no. 6 (2004): 452-60; Schroeder, "Replacing Face-to-Face Information Literacy Instruction," 77.

21. M. Foley, "Putting the Library at Students' Fingertips," Journal of Electronic Resources Librarianship 24, no. 3 (2012): 167-76; Corrall and Keates, "The Subject Librarian and the Virtual Learning Environment," 39.

22. York and Vance, "Taking Library Instruction into the Online Classroom," 200.

23. Giles, "Reflections on a Privilege," 262.

24. Barr, "Reaching Students Where They Go," 292.

25. Black and Blankenship, "Linking Students to Library Resources through the Learning Management System," 460.

26. Kellam, Cox, and Winkler, "Hacking Blackboard," 349-63.

27. Jason Casden, Kim Duckett, Tito Sierra, and Joseph Ryan, "Course Views: A Scalable Approach to Providing Course-based Access to Library Resources," code4libjouranls 6, 3-30, available online at journal.code4lib.org/articles/1218.

28. Foley, "Putting the Library at Students' Fingertips," 173.

29. Daly, "Instruction Where and When Students Need It," 79-91.

30. Jackson, "Integrating Information Literacy into Blackboard," 459.

31. Mestre et al., "Learning Objects as Tools for Teaching Information Literacy Online," 249.

32. Corrall and Keates, "The Subject Librarian and the Virtual Learning Environment," 45. 207.

33. Rieger, Horne, and Revels, "Linking Course Web Sites to Library Collections and Services,"

34. Glenda Morgan, "Faculty Use of Course Management Systems" (Boulder, Colo.: EDUCAUSE Center for Applied Research, 2003), available online at www.educause.edu/library/ resources/faculty-use-course-management-systems [accessed 1 March 2014].

35. Morgan, “Faculty Use of Course Management Systems," 2-3.

36. Ibid. 